УДК [821.161.2:050(477.83-25)”1917/1918”]: [94:355.318(477)]

Ірина Роздольська

\title{
ЖУРНАЛ "СВІТ» ЯК ЛІТЕРАТУРНА ПЛАТФОРМА УКРАЇНСЬКИХ СІЧОВИХ СТРІЛЬЦІВ
}

\section{Вступ}

Ілюстрований журнал літератури і мистецтва «Світ» (Львів, 1917-1918) ще не мав узагалі літературознавчої комплексної уваги до літературної присутності у ньому авторів із кола січових стрільців. Видання згадує спорадично Т. Стефанишин насамперед у зв'язку iз творчим феноменом Миколи Голубця, потрактовуючи результатом його небуденної особистості, як і журнал «Шляхи», виводячи генезу ідейно-змістового спрямування журналу «Світ» зі стрілецьких «Шляхів» у першому тематичному пріоритеті видання вказуючи «хроніку й популяризацію військових звитяг УСС-ів» (Стефанишин, 2009: 661). У другому тематичному пріоритеті М. Голубця Т. Стефанишин виокремлює «українську мистецьку культуру» (Стефанишин, 2009: 661), який став наслідком його наукових мистецтвознавчих зацікавлень. Дослідник встановив провідну роль М. Голубця у новому видавничому проекті на основі його листування із Богданом Заклинським, особливо у посиленні культурологічної лінії, створенні некомерційного проекту (Стефанишин, 2009: 661), вважаючи авторським самостійним проектом (Стефанишин, 2005: 8). Досліднику-мистецтвознавцеві $є$ важливішим культурологічний напрямок видання, а не стрілецький літературно-меморіальний, який у часописі розвивали автори стрілецького кола, теж повноцінно досі не «прописані» у історії літератури. Таким чином окреслюється дослідницька лакуна. Першим згадує про журнал «Світ» у стрілецькому контексті історик М. Лазарович, як про такий, що прагнув бути у ролі стрілецького органу (Лазарович, 2016: 8), зазначаючи про фінансову підтримку видання «зі стрілецьких фондів» (Лазарович, 2016: 267). Припинення виходу у березні 1918 року учений пов'язує із переїздом УСС на (C) Ірина Роздольська , 2020

http://dx.doi.org/10.34142/2312-1076.2020.1.95.09 
164 Наукові записки ХНПУ ім. Г.С. Сковороди. Літературознавство, 2020, вип. 1(95)

Наддніпрянську Україну (Лазарович, 2016: 268). Серед стрілецького літературного доробку вирізняє актуальністю праці В. Дзіковського, поезії Ю. Шкрумеляка та Р. Купчинського і прозу А. Бабюка (Лазарович, 2016: 268), які ще не аналізувалися.

Отже, бачимо, що літературний стрілецький профіль у виданні потребує окреслення, а саме видання - з'ясування концептуальнотематичних параметрів як стрілецького часопису, що становить мету нашої піонерської праці.

\section{Методологія і методи дослідження}

Для реалізації завдань методологічно опиратимемося на принцип історизму, з увагою до культурно-історичних концептів «духу часу», «середовища», «моменту», без чого літературний феномен стрілецтва як специфічної військової соціальної спільноти в умовах здійснення визвольної місії окреслити важко, оскільки світоглядною домінантою військового покоління залишилась рушійна стрілецька визвольна ідея. В інтерпретації письменницької постави і художнього образу світу звертатимемо увагу на домінантні екзистенційні семи, спровоковані дискурсом буттєвого катастрофізму в межах екстремів «життя» $\mathrm{i}$ «смерть» та антиколоніальною поставою соціальної групи, отож спиратимемось на здобутки національно-екзистенціального, постколоніального, психоаналітичного підходів. У спробі реставрації літературно-видавничої структури журналу з увагою до соціологічних ідей П. Бурдьє (Бурдье, 2000) прагнемо відчитати наміри військової спільноти творити літературну індустрію, інформаційне поле.

\section{Результати та дискусії}

Перше число вийшло 15 лютого 1917 р., останнє - у «марці» 1918 р., усього тринадцять, меншого об'єму порівняно із «Шляхами». На останній сторінці першого числа вказано, що видання редагує М. Голубець, за редакцію відповідає Д. Лукіянович (Голубець, 1917, ч.1: 16), згодом М. Голубець став цілковито «відповідати за редакцію» (Голубець, 1917, ч.4: 72). Прикметно, що на титулі значиться третій рік видання, що утверджує в думці остаточно бачити «Світ» хронологічним продовженням стрілецьких «Шляхів», новим 
його етапом. Назва часопису асоціює із молодомузівським журналом «Світ», однак нове видання «молодомузівської» естетичної ідентичності не транслює, а лише стрілецьку військову.

У редакційному зверненні «На порозї», оголошуючи часопис придатним для українських родин і їхніх духовних потреб, упорядники журналу актуалізують дві задачі, здійснивши які, суттєво прикладуться до збагачення української культури: «Маємо на думці Українське Стрілецтво $з$ одного боку і українську артистичну культуру з другого боку» (Голубець, 1917, ч.1: 2). Стрілецька тема визнана найбільш актуальною, оскільки ії сучасники і свідки свідомі тієї грандіозної місії, що іiї здійснює стрілецтво на полі бою і в умах українського громадянства. Колектив чується зобов'язаним до цього, наголошуючи «раз а раз повертатимем очі народу туди, борються і гинуть молоді герої» (Голубець, 1917, ч.1: 2). Війна пришвидшила створення українського мілітарного середовища, яке усвідомлює власну вояцьку окремішність, виростаючи на «нову появу українського життя», ставши українською національною армією. Редакція висловлює гордість із того, що доводиться бути свідком ії становлення «в усій величі і славі», обсервувати іiі «ясне і отверте» обличчя, бути причетними, учасниками., і готовність надавати моральну і громадянську підтримку стрілецькій озброєній молоді, сприяти засвоєнню національною громадою стрілецької ідеології, іï іншої духовної спадщини, щоби та стала повноцінною національною спадщиною: «...Треба, щоб ідеольогія тих, що кождої хвилі готові покласти життя в обороні народу, вросла в кров і кість усього народу. Треба, щоб ясна і повна картина Українського Стрілецтва перейшла в спадщині грядучим поколінням» (Голубець, 1917, ч.1: 2). Тут присутня артикуляція того стрілецького кредо, що його вояки сформулювали іще у перший рік Першої світової війни, творячи «Пресову кватиру» і визначаючи лінії власної культурної стратегії у військовому середовищі.

Рубрикація змісту у «Світі» здійснювалась за зразком «Шляхів», родо-видовим та тематичним принципами, адже маємо тотожні рубрики «Поезія», «Белєристика», «Спомини, некрольоги», «Запискки», «Оповістки», «Популярно-наукові статті», «Література», 
«Воєнщина», «Ілюстрації», «Світлини». Стрілецька тема також виходить за рамки рубрики «Воєнщина». У рубриці «Поезії» підтримують стрілецьку тематику автори стрілецького військового кола В. Атаманюк, А. Бабюк, М. Козіцький, Р. Купчинський, Л. Лепкий, Ю. Шкрумеляк. «Белєтристика» увиразнює воєнну тему у представленні М. Яцківа, «Воєнщина» охоплює публікації мемуарно-документального, хронікарського та художнього характеру і персоналії А. Бабюка, В. Дахнівського, В. Дзіковського, Л. Лепкого.

У рубриці «Науково-популярні статті» стрілецтво в особах В. Дзіковського та О. Назарука має змогу апробувати розвідки з історії, авторського права. У рубриці «Література» зібрані літературно-критичні відгуки на актуальні видання із переважанням стрілецьких публікацій. У рубриці «Ілюстрації», репрезентовано творчий силует стрілецьких митців О. Куриласа. І. Іванця, Л. Геца, О.Р. Сорохтея, «Світлини» ж фіксують для історії портрети стрілецьких типів у військовій обстановці, творчій праці, парадні та буденні - сотника С. Горука, хорунжого Ф. Черника, сотника Р. Дудинського, четарів О. Суховерського, П. Дідушка, стрільця і скульптора М. Гаврилка, а також військові екстер'єри. Також часопис прихильний і авторам, українським ветеранам австро-угорського війська, не легіонерам, зокрема А. Волощаку, Юркові Гринюку, письменникам старшого покоління, Д. Лукіяновичу, У. Кравченко. В. Щурату, толерує автопрезентацію творчості під псевдонімом, власне маємо учасника із номеном «Невідомий».

Підбиваючи підсумки видавничого року, редакція зауважила, що не все запрограмоване зреалізувалося, однак переконалась у правильності пріоритетів, які будуть збережені на наступний рік. Сдине, що майбутні матеріли про Українське січове військо будуть подаватися «тільки в белєтристиці» (Голубець, 1917, ч.10: 167).

У журналі меморіальна тема «тих, що полягли» отримує продовження, редакція розвиває концепцію героя за двома імперативами пам'яті полеглим і слави живим, об'єднуючи обидва головним стрілецьким завданням - здійсненням визвольної місії через пам'ятання 
і чин, через літературно-мистецьке, документальне окреслення персоналій, простору на перетині героїки і трагіки.

Вже перше число «Світу» актуалізує концепцію «Шляхів» образом «тих, що впали» в мемуарному белетризованому етюді нового автора Василя Дахнівського «Семиковецькі могили». Проходячи семиковецькими полями, після битви коло села, стертого $з$ лиця землі війною, згадуючи вигляд села до війни із пасторальними вишневими садочками, замаєними квітниками обійстями, автор порівнює із нинішньою пусткою, рефлексує про надзвичайні історичні події, пов'язані із окресленим місцем як простором стрілецької і національної пам'яті. Видимі деталі цього екстер'єру підкреслюють його особливий статус святого місця - густо засадженого надмогильними хрестами серед ланів збіжжя і бур'яну, і рясного макового кривавого цвіту маку. Поле битви позначене і табличками із «нашими написами», що сукупно творять мартиролог поляглих «у бою з Москалями 1. XI. 1915 за волю Українського народа» (Голубець, 1917, ч.1: 4), цілі шеренги прізвищ, підземний легіон, «стрілецьку долину». Образом, що концентрує у собі ідейний зміст твору, виступає стрілецький курган, висока шестиметрова могила, яку живі товариші насипали на вічную пам'ять своїм мертвим товаришам і тому бою, що в стрілецькій історіографії вважається третім великим подвигом стрілецтва, увінчаним перемогою, після Маківки і Болехова (Гнаткевич, 1991: 50). Стрілецький курган у художній візії автора перетворюється на космотвірну точку нової України, центр світу: «3 могили видно далеко - широко. А кругом безмежні поля - степи... На обріях мріють села і лїсочки в степах маленькі оази хутірців, та пасіки... В шовкових травах вєть ся сріблиста Стрипа і гине в шуварі, а там знов вибігає і вєть ся срібною лентою аж ж темного раковецького ліса. А вгорі по синій блакиті - котить ся жарке сонце, співають жайворонки, дрожить воздух. Ясне проміння спливає на стрілецькі могили і граєть ся в красці хрестів» (Голубець, 1917, ч.1: 4). Пейзаж 3 допомогою кольористики, поєднання жовтого і синього на землі і небі, перетворюється на національну емблему. А в мемуарно-історичному нарисі В. Дзіковського, наскрізному у журналі за 1918 рік, 
деталізовано усі обставини затяжних семиковецьких боїв (Голубець, 1917, ч.1-3: 7-9,21-24, 42-44).

Темою Маківки об'єднано мартиролог поляглих при іï обороні і в нарисах В. Дзіковського, і «А. Бабюка «Герої Маківки», «УСС ранені на горі Маківці», сукупно уміщених у четвертому числі. Автори скеровані поіменно відзначити кожного учасника, його небуденні прояви, особливо тих, хто у вічності, що стає стрілецьким лейтмотивом: «Вірні сини України, що сплять вічним сном у тих могилах, вказали шлях, прояснили його і ним попростують грядущі покоління до здійснення своїх мрій - подій» - підкреслює А. Бабюк (Голубець, 1917, ч.1: 66).

У пейзажно-філософській поезії В. Атаманюка «Ах коби знать!..» ліричний герой, вбираючи всім єством красу навколишнього світу, красу природи, фіксуючись на плині власних вражень від блиску сонця, рясного килима квіток, весняного пробудження трав, води, дерев, ступаючи ногами по землі, ставить собі важливе для тогочасся питання: «А я ходжу по долині. / По святині, чи пустині, / Чи як би це знать?...Ах, коби то знать?» (Голубець, 1917, ч.3: 44). Автору-стрільцеві залежить на такому знанні і так актуалізується і реалізується мотив пам'ятання, окремий реквієм. У іншому поетичному творі це місце отримує означення оксиморонне - польового цвинтаря, завдання якого зрощувати не зерно і зело, а пам'ять: «А там в полі, там в діброві /хрести білі, березові /Поставали, похилились. Затужили, зажурились... // Простелив ся хміль по гробі /Мов у тузі мов в жалобі / Легіт ледво-ледво шепче: Спіть нещасні крепче, крепче» (Голубець, 1917, ч.9: 142). Ліричне «я» А. Бабюка у поезії «Плач землі» акцентує на значенні такого простору як місця страждання, Голгофи, зрошеного жертовною кров’ю, тому і сприймає тотожно, як святе місце: «Земля ридала 3 болю й тривоги / Зрошена кровю власних дітей» (Голубець, 1917, ч.3: 38). А ліричний герой Ю. Шкрумеляка фіксує складний психологічний стан провини живих перед мертвими побратимами за своє збережене життя у поезії «заграла сурма боєва»: «...3 борні побідні йшли борці... / Керваві кидали 
мечі - Й братам гроби копали. / І диво! Кожен з них ридав, - / Що сам не впав!» (Голубець, 1917, ч.5: 75).

Усі місця слави витворюють загальнострілецький простір пам'яті, який поєднує могили героїв із хронологією подвигів, визначних дат. Із великим зворушенням Ю. Шкрумеляк написав до річниці стрілецьких боїв на Маківці поезію-алегорію героїчного змісту «Їх заповіт», де син старенького дуба карпатського, молоденький борець, «клав свою голову» навіки, але зміг відсунути Великана, тобто московське військо. Оскільки місія не завершена, «забить його була їм вже не сила», на гробах плачуть хрести. Фінал твору риторичний, із формулюванням гасла-заповіту живим, формулюванням місії: «Як ми усі / Лягли ось тут - так вам ми показали, / Як за народ бороти ся вас слід! / Ми тут лягли - лишаєм заповіт: / Щоби ви врагові панувать не дали /На своїй рідній, батьківській землі, /Як ми усі...» (Голубець, 1917, ч.4: 54-55).

Третій рік бойових дій спонукує стрілецтво розглянутися «по своїй хаті і по свому полю» і збагнути страшні наслідки геополітичної катастрофи, яка ще не закінчилась. Перед зором постають зрівняні із землею села, сади, спотворені снарядами поля, замасні хрестами, знищені пам'ятки національного значення - старовинні храми, зовнішні зміни простору. Труна стає не лише новим модулем світобудови у війни, але і тим концептом, який допомагає тлумачити загальний образ світу у стані катастрофи і буттєвий стан мешканця цього світу, що увиразнено у поезії «Невідомого» «За роком рік»: «За роком рік минає; понад нами / Життя танок проносить ся, а ми, / Немов мерці з отвертими очима / триваєм в снї на яві. Мов мерці, /Яким життя оставило свідомість, / А взяло все без решти. Крізь труну /Ми бачим вир часу, життя, подій, /А сили в нас немає, щоб долоню / піднять, або застигле серце з груди / Ухопить ціпко, вирвати з коріннєм / I кинути під колесо часу» (Голубець, 1918, ч.10: 158). У сприйнятті поетичному Л. Лепкого (поезія «Весною») війна це кров і пекло, що порушує природний колообіг пір року, у стані кінця світу пори року невпізнавані, замість очікуваного грюкоту грому - канонада вибухів, «на облаках огонь», а птахам, ще гірше, 
як старозавітній голубці Ноя, - їм немає куди вертати, немає рідних стріх (Голубець, 1917, ч.6: 93).

Поняттям «руїни» означує М. Голубець спостережені зміни, болить серце за тим, що вже не відновиться, рукотворні цінності, адже, як зазначає Редакція, «іде 3 димом добуток народу», «той що нічим його заступити не вдасться» (Голубець, 1918, ч.3: 38). Серед ілюстративного матеріалу у журналі чимало репродукцій стрілецьких робіт, у яких зафіксовані силуети церков, світських будівель, фрагменти культурних артефактів. М. Яцків тему смерті мистецтва у військовій катастрофі розгортає в музично-філософській новелі «Гомін будучини» Автор зазначає, що «в пору війни терплять не лише люди і звірята, терплять і гинуть також мертві річи» (Голубець, 1917, ч.5: 76). У фабулі твору зняли з церкви дорогоцінний старовинний дзвін на потреби армії, щоб вилити із нього гармату. Коли пускали дзвін із дзвіниці, серце його «вдаряло в криси, дзвін як би просив ся на пращаннє зі своєю двістілітньою висотою». На землі вирвали з нього серце, розбили важкими молотами на друзки його тіло. I новелістичний поворот - «дзвін мав в собі три четвертини срібла, одну домішки» і не годився на гармату: «Сей відмовив нам послуху, - замітив знавець металів і потер долонею чоло. - Шкода., що намучили ся ми стільки коло него...» (Голубець, 1917, ч.5: 76). А що вже казати про переживання людини у цій катастрофі, які змінюють їі через набуття межового досвіду.

М. Голубець у представленні картини А. Бекліна «Війна» як живий свідок і причетний підсумовує про визначальне життєве значення безпосереднього досвіду воєнної катастрофи не лише для окремих одиниць, а цілого покоління: «Наше покоління знало війну з історичних ілюстрацій. ... ніхто не уявляв собі того страхіття, тої безпощадности, жорстокости і насильства, а разом 3 тим ширини, величі і сили, всього того, що нам довело ся почути, побачити пережити» (Голубець, 1917, ч.1: 16).

Руйнівний вплив воєнної бурі відзначено на рівні приватного життя, так у стрілецькій поезії з'являється мотив зірваних війною стосунків, який проявляється не лише в епізоді прощання стрільця 
iз дівчиною, що вже є типологічним. На третьому році війни він із епізоду виростає до рівня трагедії - прощання навіки, як у поезії Ю. Шкрумеляка «Пращання»: «Я йду від тебе... Без провідника / Іду у світ. - Чи справді йду навіки?..» (Голубець, 1917, ч.8: 122). «Т.С.» у історично-документальному репортажі «Калиновець (Зима 1915)» зауважує про один із можливих станів - «самотності і безпорадності» - мов серед океану», готовності до смерті, навіть очікування іiі «Скорша смерть, менше муки» в тій інколи безпросвітній какофонії бою (Голубець, 1917, ч.2: 19).

А. Лотоцький у поезії «Я бачив їх» печать екстремального життєвого досвіду відчитує на лицях товаришів, але прочитує конструктивно, у контексті мілітарної стрілецької характерології, від блідості напруження через невідомість i, можливо, страху і тривоги, до свідомої затятості і готовності на все, у психологічному переході від юнака до мужа: «Я бачив їх. Вони ішли / У перший бій, /Ішли в квітках, / Співали запальних пісень. /А лиця їх бліді. // Я бачив їх. Вони ішли / У сотий бій / Ішли без квіток, / Німіі, без пісень ішли, / А лиця сталеві» (Голубець, 1917, ч.2: 19).

Психологічною відповіддю живої людини, налаштованої конструктивно до буття, до світу, яка прагне жити, - $є$ увага до проявів життя навколо, до пробудження життя, постає переживання руху світу від танатосу до еросу, що приходить і у творчість. Природно, що тема оновлення природи домінує в ліриці стрільців, інтимізує спектр мотивів, надає філософсько-медитативних інтонацій. Л. Лепкий динамічно передає ритм весняного пробудження нанизуванням дієслів доконаного виду, щоб передати масштаб змін: «Здригнула ся землі, / В подільську тиху ніч, / Поніс ся дужий клич: Весна!... Розприс ся лїд, / ...УДарив в беріг став. / Весняний дощик впав...» (Голубець, 1917, ч.2: 24). У Ю. Шкрумеляка поезія стає способом висловити захоплення від краси, глорифікувати усі їі прояви - і в природі, і в людині: «Ті ясні зорі, що разом побравшись /Дуть повагом молочним шляхом, /твоїй красі хай хвальний гимн заграють - святий псалом...» (Голубець, 1918, ч.1: 2), шукати красу у взаємності (Голубець, 1917, ч.7: 111). 
Стрілецький характер став тією психологічною точкою опори, яка зберегла психіку від деструктивних впливів середовища, присутність вищої цілі дисциплінувала душу, зберігала душевну цілісність, перешкоджала психічній атомізаціі. Літературні твори стрільців у журналі, біографічні сильвети побратимів і керівників підкреслюють позитивну налаштованість до життя стрілецьких типів, конструктивну атмосферу взаємної життєвої комунікації стрільців і на позиціях, і на відпочинку, і у фізичній праці, що сприймається позитивно не лише серед українського населення на Поділлі, але i юдейського, що «в доказ симпатії і любови підтягали за стрільцями» пісню (Голубець, 1917, ч.4: 71).

У концепції героя-стрільця, прикмети характеру автори намагаються увиразнити 3 допомогою живого прикладу, творячи власний «іконостас» авторитетів. Зразковою бачать поведінку у бою, вияв хоробрості і загалом концентрації духу. Таким у нарисі В. Дзіковського «Маківка» зображено четаря Кучабського, що в бою за Маківку один виступив проти «цілого ворожого рою», «неустрашимий хорунжий Коберський, а також «славні хорунжі Свідерський, Степанівна». 3 молодших рангом - це «холоднокровні четарі» Мельник, Артимович, Каратницький, а ще безіменні, кого оповідач-хронікер особисто не знає (Голубець, 1917, ч.4: 57).

Рубрика «Стрілецькі сильвети» інтонована серйозно, покликана представити широкій громадськості непересічні особистості стрілецького вояцтва, що їх і самі вояки вирізняють найкращими. Реалізувати намір редакції вдалося на прикладі біографічних портретів 3 кола «старої войни» сотника Сеня Горука та хорунжого Федя Черника.

Сильвети виразно психологізовані, їхні автори - В. Дахнівський та В. Дзіковськкий скеровані представити стрілецький характер. Сень Горук був одним із найбільш люблених і поважаних офіцерів у середовищі стрілецтва. 3 великою людською прихильністю описано риси зовнішності, психологізовано погляд - «лагідних сивих очей», що дивляться на стрільця по батьківськи, водночас передають вольовий характер, залізну рішучість портретованого. Спостерігається мілітаризація характеротворчих епітетів. Хоробрість, 
холоднокровність, розважливість - прикмети характеру С. Горука як доброго стрільця і командира. У спілкуванні він - людина «товариської культури» і «лицарського обходження». До бою йшов у стані невідступності від цілі і готовності до смерті, «рішав ся радше згинути, як уступити зі становища...», так налаштовував і свій загін - не тратити віри і «надії кращого завтра», тобто представляв тип трагічного оптиміста. При цьому змальовував перед стрільцями реальну перспективу бою і не приховував від них більшої чи меншої вірогідності втрати життя (Голубець, 1917, ч.2: 26). Ділив вояцький фатум нарівні зі своїми стрільцями, був одним із них, а не керівником-зверхником. В. Дахнівський вирізняє В. Черника із кола молодших офіцерів, абсолютною відповідністю «вірному типу стрільця», iï складовим: впевненість і рішучість у бою, стрілецька почуття військової гордості і особистої честі, погорда до смерті (Голубець, 1917, ч.3: 45). У «Пісні про Черника» Р. Купчинського мілітарні здібності героя гіперболізуються відповідно до поетики народної героїчної пісні, щоправда, автор для цього використав любовну інтригу, що через втрату спокою від кохання до прекрасної дівчини хорунжий «I в злости дві російські дивізії розбив» (Голубець, 1917, ч.5: 77).

У мемуарно-документальних нарисах, які формують документально-історичний блок журналу, проступає опуклий образ стрілецького війська в походах, в перебуванні в окопах, серед усіх можливих невигод, автори мінімізують ракурс пафосного зображення, реалізовуючи намір передати щоденність стрілецького буття - не тільки в бою і стані перемоги, але і в підготовці до збройної сутички, у стані очікування. Л. Лепкий, зокрема зосереджує увагу на стрілецькому характеpi, його проявах серед несприятливої погоди у фізичній і моральній стійкості, військовій дисципліні, виконанні усіх військових приписів, включно із невербальними формами рапортування, коли закаблуки чобіт стрільця при зударі здатні «росприскати» болото. Підкреслено сумлінність стрільців у праці, як вони прокладають дорогу із кругляку «поволи, постепенно і совісно» (Голубець, 1917, ч.1: 8).

У літературно-критичних дописах із стрілецького авторського загалу виокремлено талант дебютанта і уже визнаного поета, який 
занурився у силове поле стрілецького змагу. Збірка В. Атаманюка» «Як сурми заграють до бою» свідчить стрілецькому критикові Невідомому, що «до гурту «наших наймолодших» пристав отсе новий товариш», про поетичний потенціал у звукописі, будові строфи, загалом у способі баченні і чуття, а не лише про «охоту писати» (Голубець, 1917, ч. 6: 103).

У відгуку «Невідомого» про збірку С. Чарнецького «В годині задумки» увага зосереджена не лише на збірці, а на завданнях літературної критики, яка в тенденційно налаштованого суб'єкта може стати засобом тиску і репресій щодо автора, хоча, крім похвали, митець заслуговує і на увагу середовища загалом, і зокрема, об'єктивного 3'ясування енергетичного потенціалу творчості, яке б не перетворилося на морально-суспільну опінію. Образ світу у збірці спонукує вірити авторові, співпереживати «на серіо» його тривогам-емоціям, розділяти із ним його правду. Поет попадає «в тон часу», стає речником його духу (Голубець, 1917, ч. 8: 140).

Осип Назарук формулює ідею необхідності реєстру-рейтингу національних культурних скарбів у майбутній незалежні державі Україна, що буде покликана до громадження і захисту власної нематеріальної культури. Стан війни загострив, вважає автор, увагу спільноти на умовах, в яких творці культурних професій перебувають. Йому імпонує дискусійна думка австрійського правника Йозефа Колєра про фіксування твору та його ціни в урядовому реєстрі із наданням реєстрового знака із прослідковуванням динаміки продажів і цін, що в майбутньому гарантувала б митцеві проценти від продажу і пенсійне забезпечення. Цей реєстр насамперед «свідчити-ме про смак публіки, - вважає О. Назарук, - і вказувати по певнім часі свого рода «фінансовий» напрям» штуки» (Голубець, 1917, ч.7: 110), тобто ідеться про економічні критерії успіху митця. Так автор підходить до ідеї індустріалізації мистецького ринку і забезпечення авторського права художника чи письменника, яке має насамперед реалізуватися через виплату гонорару від продажу тиражу, щоб «торговці не забирали всего зиску». І хоч тільки час рішає, «що твором штуки» $є$, мистецькі та літературні агенти дуже б прикладись до «системи реєстровання 
всего», що зв'язане із турботою про культурне надбання держави, яка потребує агентів у царині мистецтва і літератури, які б взаємодіяли між середовищами творців і видавців, покупців. Тут О. Назарук роздумує в руслі тих ідей, що їх сформулює П. Бурдьє про силове поле літератури як виробництво і як структуру (Бурдье, 2000). Також приходить до висновку, що структурне функціонування літератури як індустрії можливе лише у сприятливих державних умовах 3 одного боку, або за умови наявності капіталу у середовищі митців, чи можливості доступу до нього. Бачимо, що інтуїтивно стрілецька спільнота змагала окреслитись як структура, що продукує літературно-мистецькі цінності, їх розповсюджує, пропагує, спираючись на власні кошти, видавництва, різноманітні видавничі проекти.

\section{Висновки}

Отже, ілюстрований журнал літератури і мистецтва «Світ» (19171918) структурно і змістовим наповненням виявляє декларовану стрілецьку ідейно-естетичну ідентичність, продовжуючи концепцію «Тим, що впали», артикульовану часописом «Шляхи», доповнюючи iii концепцією героя як «того, що в боротьбі», увиразнюючи риси характеру та світоглядної постави стрілецьких трагічних оптимістів, у колі авторів об'єднуючи стрілецькі та молодомузівські сили, ще на крок наближаючи стрілецтво до реалізації власної літературної автономії. Зі «Шляхів» у виданні представлені А. Бабюк, В. Атаманюк, Р. Купчинський, Ю. Шкрумеляк, Л. Лепкий, В. Дзіковський, I. Калинович, О. Назарук, А. Лотоцький, М. Козіцький, молодомузівці М. Яцків, С. Чарнецький. С і нові учасники-дебютанти: В. Дахнівський, «Невідомий», «Т. С.». У концепції героя поєднано тему «тих, що полягли» із темою прослави живих побратимів, при чому стрілецький характер є точкою опори для екзистенційного «прямостояння» $\mathrm{i}$ «самособоюнаповнювання» у кінцесвітньому, виростає із реальних життєписів прототипів, об'єктивний і об'єктивізований мемуарно-документальною прозою, що у журналі переважає. Прикладами стрілецьких трагічних оптимістів $є$ постаті С. Горука та Ф. Черника. Образ світу розширює свої рамки за рахунок теми воєнного катастрофізму, сучасного кінця світу станом на третій рік 
війни. Тут концепт труни структурує світобудову відповідно до зовнішніх реалій, символізуючи тотальність руйнації впорядкованості приватного і суспільного порядку життя, знищення господарства, культури, національних матеріальних і нематеріальних скарбів. Ліричний герой в усвідомленні незворотності змін зовнішнього світу та внутрішньої екзистенційної переміни внаслідок межового буття фіксується на біофільній скерованості. Відбувається збагачення стрілецької лірики інтимними, пейзажно-філософськими мотивами, медитативними інтонаціями. Стрілецька критика увиразнює власний підхід до літературних явищ на перетині культурно-історичного та соціологічного підходів - для осмислення образу світу поезії активує поняття духу часу, а для обгрунтування літературно-видавничих стратегій, реалізації ідеї успіху митця звертається до соціальних та економічних чинників.

Видання постає повноцінною платформою для маніфестування стрілецькою військовою генерацією власного стану свідомості, образу колективного «ми», транслювання в інформаційний простір стрілецьких концептів. У майбутньому - широке типологічне зіставлення на синхронному рівні із іншими стрілецькими літературноінформаційними платформами, а на діахронному - із «молодомузівським» контекстом для з'ясування меж ідентичностей.

\section{Література}

Будье, П. (2000). Поле литературы. Новое литературное обозрение, 45, 22 87. Режим доступа: http://bourdieu.name/content/burde-pole-literatury Гнаткевич, Б. (Ред.). (1991). Украӥнські січові Стрільијі, 1914-1920. Львів: Слово.

Голубець, М. (Ред.). (1917-1918). Світ. Львів.

Лазарович, М. (2016). Легіон Украӥнських Січових Стрільиів: формування, ідея, боротьба. Тернопіль: Джура.

Стефанишин, Т. (2005). Культурологічна спадщина Миколи Голубця. С. Костюк \& Т. Стефанишин (Ред.). Микола Голубецьь: Бібліографічний покажчик (с. 5-24). Львів: ЛНБ ім. В. Стефаника.

Стефанишин, Т. (2009). Культурологічна діяльність Миколи Голубця періоду Першої світової війни та визвольних змагань 1918-1919 рр. 
Записки Львівської національної наукової бібліотеки України імені В. Стефаника, 1, 653-667.

\section{Reference}

Bourdieu, P. (2000). Pole literatury [Field of literature]. Novoe literaturnoe obozrenie - New Literature Review, 45, 22-87. Retrieved from http:// bourdieu. name/content/burde-pole-literatury [in Russian].

Hnatkevych, B. (Ed.). (1991). Ukrainski Sichovi Striltsi, 1914-1920 [The Ukrainian Sich Riflemen, 1914-1920]. Lviv : Slovo [in Ukrainian].

Holubets, M. (Ed.). (1917-1918). Svit [The World journal]. Lviv [in Ukrainian]. Lazarovych, M. (2016). Legion Ukrainskykh Sichovykh Striltsiv: formuvannia, ideia, borotba [Legion of the Ukrainian Sich Riflemen: formation, idea, struggle]. Ternopil: Dzhura [in Ukrainian].

Stefanyshyn, T. (2005). Kulturolohichna spadshchyna Mykoly Holubtsia [Cultural heritage of Mykola Holubets]. In S. Kostiuk \& T. Stefanyshyn (Eds.), Mykola Holubets: Bibliohrafichnyi pokazhchyk - Mykola Holubets Bibliographic index (p. 5-24). Lviv: LNB im. V. Stefanyka [in Ukrainian]. Stefanyshyn, T. (2009). Kulturolohichna diialnist Mykoly Holubtsia periodu Pershoi svitovoi viiny ta vyzvolnykh zmahan 1918-1919 rr. [Cultural activity of Mykola Holubets during the first World War and the liberation competitions of 1918-1919 years]. Zapysky Lvivskoi natsionalnoi naukovoi biblioteky Ukrainy imeni V. Stefanyka - Notes of the V.Stefanyk Lviv National Dcientific Library of Ukraine, 1, 653-667 [in Ukrainian].

\section{Анотація \\ І.В. Роздольська. Журнал «Світ» як літературна платформа Українських Січових Стрільців}

У статті вперше розглянуто літературне функціонування військового покоління Українських Січових Стрільців у літературно-мистецькому журналі «Світ», який виходив у Львові впродовж 1917 і першої третини 1918 року під редакцією молодомузівця і хорунжого УСС Миколи Голубця. 3’ясовано, що часопис розвиває літературно-ідейну концепцію, започатковану стрілецтвом у журналі «Шляхи», означену формулою «Тим, що впали», представляючи низку творів меморіальної тематики, що відповідає засадам «духу епохи» січового стрілецтва. Творчі зусилля стрільців скеровані в руслі піднесення стрілецької слави, стрілецького характеру, документально-мемуарні форми переважають над власне художніми. 
Хронотоп України у художній візії стрілецтва - простір пам'яті, польові цвинтарі, що акумулюють досвід національної боротьби, національні цінності, стрілецька ж колективна могила - космотвірна точка і центр нової України визволеного «Завтра».

Артикульовано проблему наслідків катастрофи війни у громадському та приватному житті на третій рік війни, до розкриття подробиць редакція підійшла цілеспрямовано. Концепт труни дозволяє структурувати світобудову зовні і потрактовувати образ світу художньо. Ліричний герой стрілецького світу поміж екстремами «ерос - танатос» в силу власної стрілецької світоглядної налаштованості в руслі трагічного оптимізму скерований усе-таки до еросу, інстинкту життя, хоча усвідомлює незворотність деяких змін, редукцію приватного світу, внутрішні екзистенційні переміни після межових ситуацій, зміну інших людей навколо і світу в цілому, навіть смерть краси. При цьому стрілецька поезія збагачується негромадянськими мотивами, зокрема інтимним, пейзажно-філософський, медитативними інтонаціями.

Стрілецька критика функціонує не лише як засіб підтримки стрілецького літературного продукту і духу стрілецької епохи, але і як мотиватор розвитку стрілецької літературної діяльності, спрямований у бік так званої «літературної індустрії», «літературного виробництва» (П. Бурдьє), тобто демонструє поєднання ідеалістичного історичного підходу і соціологічного.

Ключові слова: Українські січові стрільці, журнал «Світ», покоління, герой, меморіальність, мемуарність, війна.

\section{Аннотация}

\section{И.В. Роздольская. Журнал «Свит» («Мир») как литературная платформа Украинских Сечевых Стрельцов}

В статье впервые рассмотрена литературная деятельность военного поколения Украинских Сечевых Стрельцов в литературно-художественном журнале «Свит» («Мир»), выходившем во Львове в период 1917 и первой трети 1918 года под редакцией Мыколы Голубца. Выяснено, что журнал продолжает развитие литературно-художественной концепции журнала «Шляхы» («Пути»), которую можно охарактеризовать формулой «Тем, кто погиб», представляя произведения мемориальной тематики в соответствии с «духом эпохи» сечевого стрелецтва. Творческие усилия стрельцов нацелены на пропаганду стрелецкой славы, стрелецкого 
характера, документально-мемуарные формы превалируют над собственно художественными.

Хронотоп Украины в художественном представлении стрелецтва - пространство памяти, полевые кладбища, акумулириющие опыт национальной борьбы, национальные ценности. Стрелецкая же коллективная могила - космологический центр рождения новой Украины, освобожденного «Завтра».

Редакция артикулирует проблему последствий военной катастрофы в общественной и личной жизни на третьем году разрушений. Концепт гроба позволяет структуризировать живое пространство мира и истолковывать его образ художественно. Стрелецкий лирический герой между экстремумами «эрос» - «танатос» в силу собственного генерационного мировоззрения в русле трагического оптимизма устремлен к «эросу», инстинкту жизни, осознавая фатальность мировых перемен, человеческой экзистенции, даже смерть красоты. При этом стрелецкая поэзия обогащается интимным, пейзажно-философским, медитативным мотивами, дополняющими основной патриотический мотив.

Стрелецкая критика функционирует не только как средство поддержки стрелецкого литературного продукта и фиксации духа стрелецкой эпохи, но и выступает в качестве мотиватора развития стрелецкой литературной деятельности, развивающейся в направлении «литературной индустрии», «литературного производства» (П. Бурдье), демонстрируя слияние идеалистического исторического и социологического подходов.

Ключевые слова: Украинские Сечевые Стрельцы, журнал «Свит» («Мир»), поколение, герой, мемориальность, мемуарность, война.

\section{Abstract \\ I.V. Rozdolska. «Svit» («The World») magazine as a literary platform of Ukrainian Sich Riflemen}

The article for the first time examines the literary functioning of the military generation of Ukrainian Sich Riflemen in the literary and art journal «Svit» («The World»), which was published in Lviv during 1917 and the first third of 1918 under the editorship of the young musician and chronicler of USR Mykola Holubets.

It is revealed that the magazine developed a literary-conceptual vision, started by the riflemen in the «Shliakhy» («Paths») journal, designated by the formula of «The Ones Who Fell», representing a series of works of memorial subjects that corresponded to the Sich Riflemen principles of the «era's spirit». The creative 
efforts of the riflemen were directed in the line of exaltation of riflemen glory, riflemen character, documentary-memoir forms outweigh the artistic ones. The chronotype of Ukraine in the artistic vision of riflemen represented by the space of memory, the field cemeteries that accumulate the experience of national struggle, the national values, the riflemen collective grave though is the cosmogonic center of the new Ukraine liberated "Tomorrow".

The problem of the consequences of the war's catastrophe in public and private life in the third year of the war is articulated, to the disclosure of details the editorial board approached purposefully. The coffin concept allows to structure the universe from the outside and interpret the image of the world artistically. The lyrical hero of the riflemen world between the extremes of «Eros - Thanatos» because of his own riflemen world outlook on the tragic optimism, s still directed to Eros, instinct of life, although he is aware of the irreversibility of some changes, the reduction of the private world, the inner existensial changes after boundary situations, the change of other people around, and the world in general, and even the death of beaty. At the same time riflemen poetry is enriched with non-civic motifs, in particular with intimate, landscape-philosophical, meditative intonations.

Riflemen criticism functions not only as a tool of supporting the riflemen literary product and the spirit of the riflemen era, but also as a motivator for the development of riflemen literary activity toward the so-called «literary industry», «literary production» (P. Bourdieu), demonstrates a combination of sociological, idealistic and ideological approach.

Keywords: Ukrainian Sich Riflemen, «Svit» («The World») magazine, generation, hero, memorial, memoir, war.

Рукопис статті отримано 29 січня 2020

Рукопис затверджено до публікаиії 9 березня 2020

\section{Інформація про автора}

Роздольська Ірина Володимирівна - кандидат філологічних наук, доцент, доцент кафедри української літератури імені акад. М. Возняка Львівського національного університету імені Івана Франка; вул. Університетська, 1, м.Львів, Львівська область, 79000, Україна; e-mail: yaremchuk. iryna74@gmail.com; https://orcid.org/0000-0002-3308-1981 